\title{
Article \\ Pharmaceutical Products and Pesticides Toxicity Associated with Microplastics (Polyvinyl Chloride) in Artemia salina
}

\author{
María Gemma Albendín ${ }^{1}$, Vanessa Aranda ${ }^{1} \oplus$, María Dolores Coello ${ }^{2, *}$, Carmen González-Gómez ${ }^{1}$, \\ Rocío Rodríguez-Barroso ${ }^{2}{ }^{(1)}$, José María Quiroga ${ }^{2}$ and Juana María Arellano ${ }^{1}$ (i) \\ 1 Toxicology Laboratory, University Institute of Marine Research (INMAR), International Campus of Excellence \\ of the Sea (CEI MAR), Faculty of Marine and Environmental Sciences, University of Cádiz, \\ 11510 Cádiz, Spain; gemma.albendin@uca.es (M.G.A.); vanessa.arandaquiros@alum.uca.es (V.A.); \\ mgong45@oc.mde.es (C.G.-G.); juana.arellano@uca.es (J.M.A.) \\ 2 Environmental Technologies Department, University Institute of Marine Research (INMAR), International \\ Campus of Excellence of the Sea (CEI MAR), Faculty of Marine and Environmental Sciences, University of \\ Cádiz, 11510 Cádiz, Spain; rocio.rodriguez@uca.es (R.R.-B.); josemaria.quiroga@uca.es (J.M.Q.) \\ * Correspondence: dolores.coello@uca.es
}

check for updates

Citation: Albendín, M.G.; Aranda, V.; Coello, M.D.; González-Gómez, C.; Rodríguez-Barroso, R.; Quiroga, J.M.; Arellano, J.M. Pharmaceutical Products and Pesticides Toxicity Associated with Microplastics (Polyvinyl Chloride) in Artemia salina Int. J. Environ. Res. Public Health 2021, 18, 10773. https://doi.org/10.3390/ ijerph182010773

Academic Editors: Miguel Motas Guzmán and Marta Esteban López

Received: 13 August 2021

Accepted: 7 October 2021

Published: 14 October 2021

Publisher's Note: MDPI stays neutral with regard to jurisdictional claims in published maps and institutional affiliations.

Copyright: (c) 2021 by the authors. Licensee MDPI, Basel, Switzerland. This article is an open access article distributed under the terms and conditions of the Creative Commons Attribution (CC BY) license (https:/ / creativecommons.org/licenses/by/ $4.0 /)$

\begin{abstract}
Pharmaceutical products, as well as insecticides and antimicrobials, have been extensively studied, but knowledge of their effects-especially those caused by their mixtures with microplasticson aquatic organisms remains limited. However, it should be borne in mind that the state of knowledge on acute and chronic effects in aquatic organisms for pharmaceuticals and pesticides is not similar. In response, this investigation analyzed the presence of microplastics (polyvinyl chloride) and their impacts on the toxicity of chlorpyrifos (an insecticide) and triclosan (an antibacterial) when they coincide in the environment, alongside the two most consumed drugs of their type (hypolipemic and anticonvulsant, respectively), namely simvastatin and carbamazepine, in Artemia salina. LC $\mathrm{C}_{50}$ and cholinesterase enzyme activity were calculated to determine the possible neurotoxicity associated with emergent contaminants in the treatments. The $\mathrm{LC}_{50}$ values obtained were $0.006 \mathrm{mg} / \mathrm{dm}^{3}$ for chlorpyrifos, $0.012 \mathrm{mg} / \mathrm{dm}^{3}$ for chlorpyrifos associated with microplastics, $4.979 \mathrm{mg} / \mathrm{dm}^{3}$ for triclosan, $4.957 \mathrm{mg} / \mathrm{dm}^{3}$ for triclosan associated with microplastics, $9.35 \mathrm{mg} / \mathrm{dm}^{3}$ for simvastatin, $10.29 \mathrm{mg} / \mathrm{dm}^{3}$ for simvastatin associated with microplastics, $43.25 \mathrm{mg} / \mathrm{dm}^{3}$ for carbamazepine and $46.50 \mathrm{mg} / \mathrm{dm}^{3}$ for carbamazepine associated with microplastics in acute exposure. These results indicate that the presence of microplastics in the medium reduces toxicity, considering the $\mathrm{LC}_{50}$ values. However, exposure to chlorpyrifos and carbamazepine, both alone and associated with microplastics, showed a decline in cholinesterase activity, confirming their neurotoxic effect. Nevertheless, no significant differences were observed with the biomarker cholinesterase between the toxicant and the toxicant with microplastics.
\end{abstract}

Keywords: microplastics; simvastatin; carbamazepine; chlorpyrifos; triclosan; cholinesterase activity

\section{Introduction}

Currently, aquatic systems, in some cases, show a significant deterioration. Human intervention is one of the sources of water pollution; domestic, industrial and agricultural activities use and produce large quantities of substances such as insecticides, antibacterials, plastics, drugs, etc. This complex mixture of substances with plastics could be responsible for environmental pollution, since aquatic/sediment/soil organisms could be especially exposed [1-3]. Plastic waste in the environment is an increasing problem that has generated a lot attention from both researchers and the general public. This debris fragments in the environment into smaller particles, such as microplastics (MP; $<5 \mathrm{~mm}$ ), whose presence has been detected until in the Atlantic gyre [4].

The presence of pharmaceuticals and their metabolites in groundwater, lakes, rivers, oceans and so forth has been confirmed by authors such as Liu et al. (2011) [5], Biel-Maeso 
et al. (2018) [6], Barbosa et al. (2019) [7] and Primrose et al. (2019) [8]. High concentrations of simvastatin and carbamazepine have been observed in the aquatic environment due to the progressive increase in their consumption in recent decades. Simvastatin is the most consumed hypolipemic drug in Spain, having increased by 670\% since 2000 [9]. Similarly, carbamazepine is the most widely used anticonvulsant, with an increase in consumption of $41.52 \%$ since 2008 [10].

The high consumption of simvastatin and carbamazepine and their subsequent discharge into urban wastewater through human excretion, drug residues that are not properly disposed of and waste generated during their manufacture cause large quantities of drugs and their metabolites to reach wastewater stations (WWTPs) [11]. These toxic substances are not completely eliminated during treatment processes. Due to their high cost, most WWTPs do not have purification systems capable of totally eliminating pharmaceutical compounds. Instead, the effluent is typically dumped, and high concentrations of these products are maintained in aquatic ecosystems, where they can have toxic impacts on organisms [11]. Neuparth et al. (2014) [12] have shown that exposure to simvastatin disrupts the reproduction and growth of the amphipod crustacean Gammarus locusta in vivo. In vitro research has also indicated that this compound and its metabolite cause liver cytotoxicity in rainbow trout (Oncorhynchus mykiss), metabolic inhibition and loss of cell membrane integrity [13]. Carbamazepine has been found to produce harmful effects in organisms, such as moult and growth inhibition in the crustacean Eriocheir sinensis [14]; malformations during embryonic development in Mytilus galloprovincialis [15]; and neurotoxic effects, such as alterations in mobility and behavior, in Danio rerio embryos [16].

Today, a wide range of pesticides are used in agriculture and horticulture and play a key role in global food production. The main factors driving the increase in pesticide use are related to population growth, necessitating the intensified exploitation of agricultural land [17].

Chlorpyrifos (CPF) is an organophosphate that is used to control foliage and insect and arthropod pests in the soil in a variety of foods [18]. In 2019, the European Food Safety Authority confirmed a human health concern due to the possible genotoxicity and neurotoxicity of CPF. Previously, CPF had been banned in Hawaii and California [19], and it is no longer authorized for use in plant protection products in the EU from 2020. $\mathrm{CPF}$ is a typical insecticide that is difficult to dissolve in water $\left(1.4 \mathrm{mg} / \mathrm{dm}^{3}\right.$ at $\left.25^{\circ} \mathrm{C}\right)$. It can be transported from groundwater by leaching and travel in surface water via runoff and erosion [20,21]. Low concentrations of CPF in the aquatic environment cause adverse effects, such as histopathological and behavioral changes, oxidative stress, neurological damage and genotoxicity in algae, fish, crustaceans and shellfish [19].

In the group of antibacterials, triclosan (TCS) is found in the composition of many products used in our daily lives, such as soaps, shampoos, detergents, deodorants, household items, additives in packaging and textiles. TCS has antibacterial and fungicidal properties and is released into the sewage network, eventually reaching sewage treatment plants that empty into rivers and seas. TCS represents a major source of pollution [22] because exposure leads to toxicity in aquatic organisms [23]. The routes of entry of TCS in humans are through skin contact, mucous membranes and the gastrointestinal tract, because this compound is rapidly metabolized and excreted through urine. It has a low probability of generating toxic effects, whether genotoxic, teratogenic, mutagenic or carcinogenic. However, TCS has structural similarities to thyroid hormones and androgenic and estrogenic disruptors [24]. Its mechanism of action as an antibacterial is based on disrupting the membrane through blocking lipid synthesis. It inhibits the transport protein enoyl-acylreductase, which participates in the biosynthesis of fatty acids necessary for the formation of cell membranes and in the reproduction of bacteria [25].

Microplastics (MPs) constitute another emerging contaminant that has been gaining relevance in recent years. Due to their low cost and versatility, plastics are increasingly in demand, having replaced conventional materials (paper, glass, wood and metal). In 2018, the production of plastics worldwide reached 360 million tons, including 62 million tons in 
Europe. The amount of plastics generated in the world has been growing exponentially for decades, from 348 to 359 million tons during the period 2017/2018 [26].

Some plastic products have a useful life of less than one year, while others have a durability of more than 50 years, but one thing that all of them have in common is that, when their useful life is over, they become waste. The disposal of many of these plastic wastes is not properly managed, so they end up contaminating aquatic ecosystems [27]. Although there are many types of marine debris (e.g., paper, glass and metal), plastics represent $82 \%$ of this waste [28]. This plastic garbage can be classified according to its size into macroplastics and microplastics, the latter representing the majority of the total garbage released into the marine environment. As is also the case with pharmaceutical substances, MPs originated by human activity in the form of textile fibers, remains of cosmetics and industrial processes end up in the sewage system and reach the marine environment through the effluents of WWTPs, where they are not completely eliminated [29-31].

They can also act as vectors for the transportation of other pollutants, because they have additives in their composition that can be released into the environment during the fragmentation process and they have the ability to adsorb other chemical pollutants on their surfaces, including heavy metals [32], hydrophobic organic pollutants and pharmaceutical compounds [33]. From this capacity of MPs to act as vectors for other contaminants derives the importance of investigating the interaction between MPs, pharmaceutical compounds and pesticides, as these contaminants are increasingly present in aquatic ecosystems. Authors such as Rainieri et al. (2018) [34] and Webb et al. (2020) [35] have shown that the presence of MPs in the environment affects the toxicity of other pollutants.

Cholinesterase (ChE) activity inhibition is one of the biomarkers of exposure, which is widely used and recognized as a biomarker to organophosphate compounds, such as CPF [36], as well as to pharmaceutical substances. In crustaceans, Thi et al. (2009) [37] showed that the cholinesterase activity present in adult Penaeus monodon was inhibited by the action of antibiotics. Albendín et al. (2021) [38] and Soto-Mancera et al. (2020) [39] determined a decreased level of cholinesterase activity exposed to organophosphate compounds in seabream. Nunes et al. (2016) [40] found that the anxiolytic diazepam inhibited the cholinesterase activity present in Artemia parthenogenetica. Similarly, Yu et al. (2018) [41] determined that MPs significantly reduced cholinesterase activity in Eriocheir sinensis.

Relative to fish and molluscs, the use of Artemia salina in toxicity tests has many advantages. These crustaceans have a shorter life cycle, provide available populations all year and offer both a standardized method of cultivation from dried cysts and easy handling. Therefore, Artemia salina has been successfully used in toxicological tests for decades [42-44].

For the above reasons, in this study, the impacts of the toxicity of MPs (polyvinyl chloride), pharmaceutical substances (simvastatin and carbamazepine) and pesticides (chlorpyrifos and triclosan) on Artemia salina were evaluated, in order to determine whether MPs in combination with drugs or pesticides increase the adverse effects on this organism. To measure possible adverse effects, toxicity tests were performed by determining the $\mathrm{LC}_{50}$, as well as the ChE, activity.

\section{Material and Methods}

\subsection{Chemicals}

Acetylthiocholine iodide (AcSCh) (Sigma-Aldrich, Merck KGaA, Darmstadt, Germany), 5,5'-dithiobis-(2-nitrobenzoic acid) (DTNB) (Merck, Merck KGaA, Darmstadt, Germany), acetone (Scharlab, Merck KGaA, Darmstadt, Germany), 5H-dibenzo[b,f]azepine5-carboxamide (carbamazepine (CAS 298-46-4) (Sigma-Aldrich, Merck KGaA, Darmstadt, Germany),(1S,3R,7S,8S,8aR)-8-\{2-[(2R,4R)-4-Hydroxy-6-oxotetrahydro-2H-pyran-2yl]ethyl\}-3,7-dimethyl-1,2,3,7,8,8a-hexahydro-1-naphthalenyl 2,2-dimethylbutanoate (simvastatin CAS 79902-63-9, Sigma-Aldrich), 5-Chloro-2-(2,4-dichlorophenoxy) phenol (triclosan (CAS 3380-34-5, Sigma-Aldrich) and O, O-dietil O-3,5,6-tricloro-2-piridil fosforotionato (chlorpyrifos) (CAS 2921-88-2, Sigma-Aldrich) were used. Bovine serum albumin 
(BSA) and the BioRad Protein Assay were supplied by BioRad (Madrid, Spain). Polyvinyl chloride (PVC) (CAS 9002-86-2, Aldrich. The data for the compound are listed in PubChem: https:/ / pubchem.ncbi.nlm.nih.gov/ compound/6338. (accessed on 13 September 2021), $\mathrm{MP}<5 \mathrm{~mm})$, potassium dichromate $\left(\mathrm{K}_{2} \mathrm{Cr}_{2} \mathrm{O}_{7}\right)$ (CAS 7778-50-9, Panreac, AppliChem. ITW Reagents, Barcelona, Spain), di-sodium hydrogen phosphate anhydrous (CAS 7558-79-4, Merck, Darmstadt, Germany) and sodium dihydrogen phosphate monohydrate (CAS 10049-21-5, Merck, Darmstadt, Germany) were used.

\subsection{Organisms and Sample Preparation}

Artemia salina (aged 4 weeks) were obtained from the Marine Culture Laboratory (registration number ES110280000312) at the Marine and Environmental Sciences Faculty (University of Cádiz). The organisms were treated in accordance with the ethical guidelines of the European Union Council (Council Directive 86/609/EEC) and the Bioethical Committee of the University of Cádiz (Spain). Specimens were anaesthetized by immersion in ice.

The tests yielded the following results: $\mathrm{pH}=7.49-7.63$, dissolved oxygen $=75.4-$ $98.3 \%$, conductivity $=48.20-49.37 \mathrm{mS} / \mathrm{cm}$ and temperature $=20.55-21.22^{\circ} \mathrm{C}$. There were no significant variations in the parameters of the aquariums. Acclimation to laboratory conditions prior to the tests: After 28 days of decapsulation of the A. salina, the organism was kept for $48 \mathrm{~h}$ under the same conditions as during the laboratory tests but fed ad libitum.

\subsection{Exposure Experiments \\ 2.3.1. MP Intake Bioassay}

A. salina specimens were exposed to nominal concentrations of $0.26,0.69$ and $1.6 \mathrm{mg} / \mathrm{dm}^{3}$ of polyvinyl chloride in seawater, in $25 \mathrm{~mL}$ flasks, with each containing 10 adults. These concentrations were selected based on the results obtained by other authors $[45,46]$. Three replicates of each concentration, as well as a control concentration, were used. The tests were conducted according to the guidelines of the Organisation for Economic Co-operation and Development (OECD) chemical test guideline 202 [47], testing the dead/immobilization of $A$. salina. To reach the stable microplastic concentrations, a stock suspension of microplastics was added, previously stirred. MP concentrations were not quantified. After the 48-h test period, a visual analysis of the digestive system of the organisms exposed to the MP was observed under an optical microscope to check whether the specimens had ingested MP.

\subsubsection{Pesticides, Pharmaceutical Products, MPs and Reference Toxicity Test}

Potassium dichromate $\left(\mathrm{K}_{2} \mathrm{Cr}_{2} \mathrm{O}_{7}\right)$ was used as a reference test. The concentrations used were $80,40,20,10,5,2.5$ and $1.25 \mathrm{mg} / \mathrm{dm}^{3}$, as well as a seawater control. Glass flasks of $25 \mathrm{~cm}^{3}$ were used. There were 3 replicates for each treatment and 10 organisms in each flask. The exposure duration was $48 \mathrm{~h}$ at $21^{\circ} \mathrm{C}$ and $16 \mathrm{~h}$ of light $/ 8 \mathrm{~h}$ of darkness. A. salina were not fed. At the end of the test, the surviving individuals were counted; if they did not show any movement, they were considered dead. The concentrations of simvastatin and carbamazepine were $12.03,10.03,8.35,6.96,5.80$ and $52.08 \mathrm{mg} / \mathrm{dm}^{3}$; and 43.40, 36.17, 30.14 and $25.16 \mathrm{mg} / \mathrm{dm}^{3}$ in seawater, respectively. Following these tests, the concentrations of triclosan and chlorpyrifos were 12, 6, 3, 1.5, 0.75 and $0.0312 \mathrm{mg} / \mathrm{dm}^{3}$; and $0.0156,0.0078$, 0.0039 and $0.00195 \mathrm{mg} / \mathrm{dm}^{3}$, respectively.

The nominal MP concentration $0.26 \mathrm{mg} / \mathrm{dm}^{3}$ was chosen based on a bibliographic review [45] and was considered environmentally relevant. Acetone was used as the solvent due to the hydrophobic nature of chemical compounds. A control with seawater and another with acetone were used in all the tests. Eight semi-static toxicity tests with three replicates were undertaken: simvastatin, simvastatin-MP, carbamazepine, carbamazepineMP, TCS, TCS-MP, CPF and CPF-MP. Ten specimens of Artemia salina (aged 4 weeks) of approximately $8 \mathrm{~mm}$ of size were included in each flask. The solvent concentration in the 
acetone control and chemical component-only exposures was $<0.001 \% v / v$. In the MP tests, the polyvinyl chloride stock suspension $\left(0.26 \mathrm{mg} / \mathrm{dm}^{3}\right)$ was added.

Surviving and dead/immobilized organisms were counted. Surviving A. salina specimens were preserved frozen at $-80^{\circ} \mathrm{C}$, until the time of analysis. In addition, before conservation, living organisms from the tests with MPs were observed under an optical microscope to check whether they had ingested the MPs.

\subsubsection{Sample Preparations}

After euthanasia by ice, the samples were stored at $-80{ }^{\circ} \mathrm{C}$ until processing. The surviving A. salina from each concentration were rapidly thawed and homogenized cold at the rate of $100 \mu \mathrm{L}$ of phosphate buffer $(0.1 \mathrm{M} \mathrm{pH} 7.4)$, using an Ultraturrax homogenizer and centrifuged at $9000 \mathrm{~g}$ for $30 \mathrm{~min}$ at $4{ }^{\circ} \mathrm{C}$. The supernatants of each sample were then collected.

\subsection{Enzymatic Assays}

ChE activity was measured according to the Ellman et al. (1961) [48] method, adapted for use with a microplate reader as previously described by Albendín et al. (2017) [49]. Briefly, $50 \mu \mathrm{L}$ of sample was mixed with a mixture containing $30 \mathrm{~cm}^{3}$ of $0.1 \mathrm{M}$ phosphate buffer (pH 7.4), $1 \mathrm{~cm}^{3}$ of DTNB $0.01 \mathrm{M}\left(0.27 \mathrm{mM}\right.$ : final well concentration) and $0.2 \mathrm{~cm}^{3}$ of ASCh $0.2 \mathrm{M}$ (1.07 mM: final well concentration). The change in optical density over time was recorded at $415 \mathrm{~nm}$ for $3 \mathrm{~min}$.

The protein content of the samples was measured using Bradford's (1976) [50] method, adapted to microplates using bovine serum albumin as the standard. All enzyme and protein determinations were prepared in triplicate at $25^{\circ} \mathrm{C}$. ChE activities were expressed as nmol hydrolyzed substrate $/ \mathrm{min} / \mathrm{mg}$ of protein. The specific activities are reported below as the mean $\pm \mathrm{SD}$.

\subsection{Data and Statistical Analysis}

The mortality data were treated with the program of the Environmental Agency of the United States (EPA-USA), probit method. The values of $\mathrm{CL}_{50}$ for all the chemical compounds individually and associated with the MPs were studied.

Cholinesterase activity data were statistically analysed using the IBM SPSS Statistics (IBM, Madrid, Spain) for Windows Version 23 program. Assumptions regarding the data's normality and homogeneity of variance were tested by using the Shapiro-Wilk test and Levene's test, respectively. When the assumption of normality was not satisfied, the Kruskal-Wallis test was used to determine whether there was any significant difference and the Tukey or the Mann-Whitney $U$ test was used to determine between which groups there was a significant difference. Statistical differences between groups were accepted for $p$-values lower than 0.05 .

When the assumption of normality was followed, a one-way analysis of variance (ANOVA) was employed to assess the differences of AChE activity among the different chemical compounds, followed by Dunnet's post hoc comparison test.

\section{Results}

\subsection{Toxicity Reference Test}

The $\mathrm{LC}_{50}$ value of $\mathrm{K}_{2} \mathrm{Cr}_{2} \mathrm{O}_{7}$ during the 24 -h duration of the test was $11.80 \mathrm{mg} / \mathrm{dm}^{3}$. The values obtained for the lower and upper confidence limits, both of $95 \%$, were 8.75 and $16.07 \mathrm{mg} / \mathrm{m}^{3}$, respectively.

The database of the State Agency for the Protection of the Environment (EPA) has established that the $\mathrm{LC}_{50}$ value for this toxic substance in acute toxicity tests on invertebrates should be in the range of $0.067-59.90 \mathrm{mg} / \mathrm{dm}^{3}$. When the value obtained for $\mathrm{K}_{2} \mathrm{Cr}_{2} \mathrm{O}_{7}$ was found, i.e., $\mathrm{LC}_{50}$ of $11.80 \mathrm{mg} / \mathrm{dm}^{3}$, which is within this range, it was determined that the quality of the $A$. salina population was optimal for carrying out subsequent tests with the substances. 


\subsection{Toxicity Test: Pharmaceuticals, Pesticides and MPs}

In Figure 1, the samples of MPs and digestive tract of A. salina in the control group are observed. Artemia salina ingested MPs during the $48 \mathrm{~h}$ exposure experiments at all the concentrations exposed $\left(0.26,0.69\right.$ and $1.5 \mathrm{mg} / \mathrm{dm}^{3}$; Figure 2$)$, as particles were detected in the digestive tract. These nominal concentrations were used to check whether the MPs indeed accumulated in A. salina. In the subsequent tests, the lowest concentration was used, so it can be considered ecologically relevant [51].
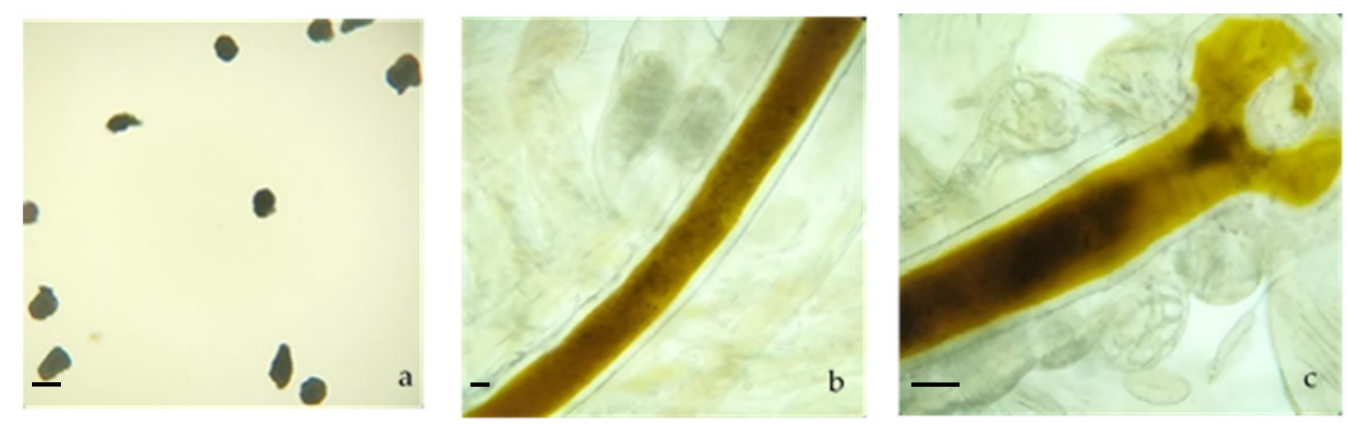

Figure 1. MPs and Artemia salina: (a) MPs used in the tests, (b) Artemia salina control without MPs after $48 \mathrm{~h}$ and (c) Artemia salina mouth control without MPs after $48 \mathrm{~h}$. Scale bar (a-c): $200 \mu \mathrm{m}$.
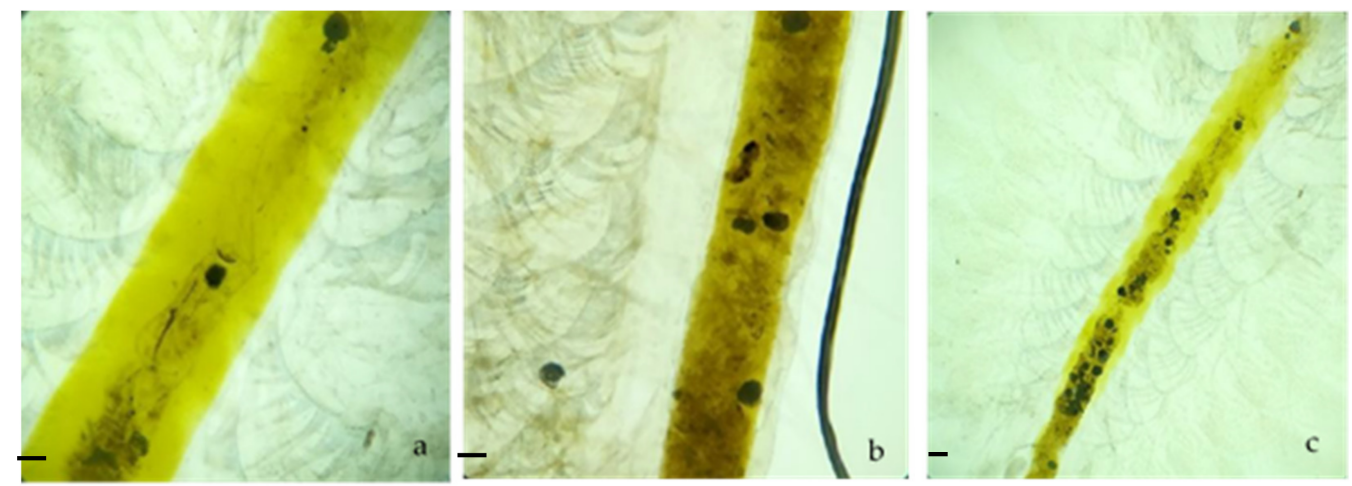

Figure 2. Artemia salina after $48 \mathrm{~h}$ of exposure to different MP concentrations: (a) $26 \mathrm{mg} / \mathrm{dm}^{3}$ of MPs, (b) $0.69 \mathrm{mg} / \mathrm{dm}^{3}$ of MPs and (c) $1.5 \mathrm{mg} / \mathrm{dm}^{3}$ of MPs. Scale bar (a-c): $200 \mu \mathrm{m}$.

The organisms that had ingested MPs were counted. No mortality was recorded in any of the concentrations or in the seawater control during the test. The number of $A$. salina with MPs increased with concentration (Table 1). In the lowest concentration used, $16.6 \%$ of individuals had ingested MPs.

Table 1. Quantification of MPs in the digestive tract of Artemia salina. Number of organisms in which MP was detected (MP)/number of organisms in which MP was not detected (No MP).

\begin{tabular}{ccccc}
\hline & & Sample Replication & Total \\
\hline MP & MP/No MP & MP/No MP & MPs/No MP & MPs/No MP \\
\hline $0.26 \mathrm{mg} / \mathrm{dm}^{3}$ & $2 / 8$ & $2 / 8$ & $1 / 9$ & $5 / 30$ \\
\hline $0.69 \mathrm{mg} / \mathrm{dm}^{3}$ & $4 / 6$ & $5 / 5$ & $2 / 8$ & $11 / 30$ \\
\hline $1.5 \mathrm{mg} / \mathrm{dm}^{3}$ & $3 / 7$ & $7 / 3$ & $9 / 1$ & $19 / 30$ \\
\hline
\end{tabular}

MPs were found in the digestive tract of the surviving A. salina of the simvastatin and MP test; these were detected in 58 of the 127 specimens exposed to MPs that survived. In the carbamazepine and MP test, these were found in 71 of the 130 that survived. Meanwhile, in the CPF + MP and TCS + MP test, these were not observed. 
The mortalities recorded in tests where organisms were exposed to different increasing concentrations of simvastatin, simvastatin-MP, carbamazepine, carbamazepine-MP, TCS, TCS-MP, CPF and CPF-MP, as shown in Figure 3.
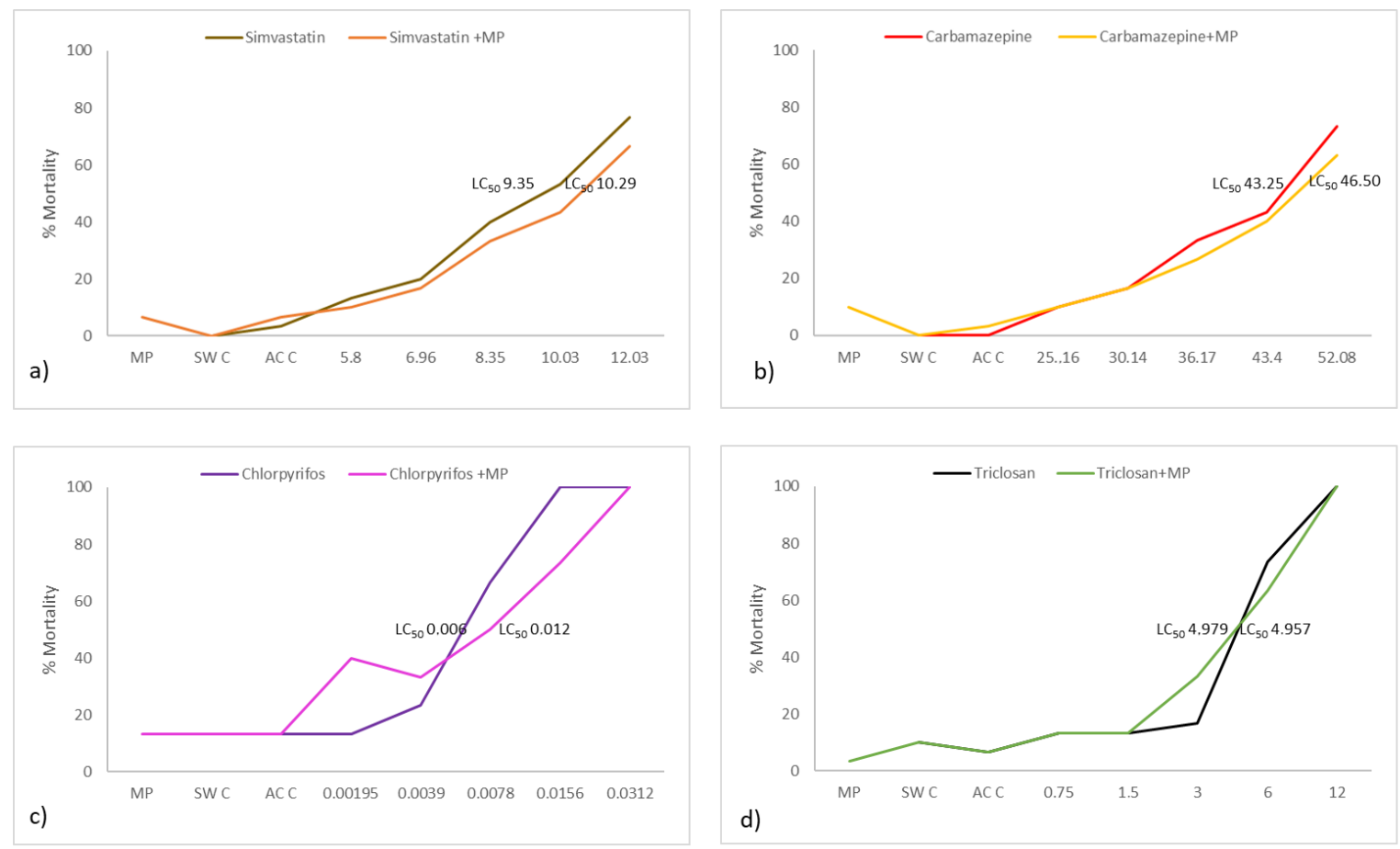

Figure 3. Mortality rate of $A$. salina after $48 \mathrm{~h}$ of exposure to different contaminant concentrations $\left(\mathrm{mg} / \mathrm{dm}^{3}\right):(\mathbf{a}) \operatorname{simvastatin}$ and simvastatin + MP; (b) carbamazepine and carbamazepine + MP; (c) CPF and CPF + MP; and (d) TCS and TCS + MP. Mean values are represented. SW C: Seawater Control; AC C: Acetone Control.

The toxicity acute test showed lower mortality in organisms exposed to simvastatin and MP together compared to simvastatin alone. At the lowest concentrations (5.80 and $6.96 \mathrm{mg} / \mathrm{dm}^{3}$ ), the mortality difference was slightly smaller in this test, becoming more marked in the concentration of $8.35 \mathrm{mg} / \mathrm{dm}^{3}$. At the highest concentrations $(10.03$ and $12.03 \mathrm{mg} / \mathrm{dm}^{3}$ ), the difference in mortality between the two assays was greatest, being $10 \%$ in both concentrations. In the visual controls that were carried out during both tests, no alteration was observed, neither in the physiology nor in the behavior of the organisms. The same mortality rates $(10 \%$ and $16.66 \%$, respectively) occurred in A. salina exposed to concentrations of 25.16 and $30.14 \mathrm{mg} / \mathrm{dm}^{3}$ in the tests with carbamazepine only and carbamazepine associated with MPs. The greatest mortality difference (10\%) between the treatments occurred in the concentration of $52.08 \mathrm{mg} / \mathrm{dm}^{3}$ of carbamazepine.

The organisms did not manifest changes in physiology, even though they did in their behavior. A. salina survivors at concentrations of 30.14 and $36.17 \mathrm{mg} / \mathrm{dm}^{3}$ in both assays exhibited slow mobility with respect to the control, including alternating periods of immobility with periods of fast swimming movements with respect to the control. At the highest concentrations of 43.40 and $52.08 \mathrm{mg} / \mathrm{dm}^{3}$ (carbamazepine and carbamazepine $+\mathrm{MP}$ ), $A$. salina did not show mobility and only reacted when mechanically stimulated with a glass rod.

Comparing the CPF treatments with and without MP, at the lowest concentrations $\left(0.00195\right.$ and $\left.0.0039 \mathrm{mg} / \mathrm{dm}^{3}\right)$, we see that the percentage of mortality was lower in the chlorpyrifos test versus chlorpyrifos and associated MP, but at higher concentrations $(0.0078$ and $0.0156 \mathrm{mg} / \mathrm{dm}^{3}$ ), the pattern changed, mortality being lower for chlorpyrifos and MP. At the concentration of $0.0312 \mathrm{mg} / \mathrm{dm}^{3}$, there was $100 \%$ mortality in both tests.

The mortality at 0.75 and $1.5 \mathrm{mg} / \mathrm{dm}^{3}$ did not differ in the triclosan test with and without MP. At a concentration of $12 \mathrm{mg} / \mathrm{dm}^{3}$, there was $100 \%$ mortality in both tests. 
In general, at the highest concentrations, mortality was slightly lower in tests where the toxicant was associated with MP, but they were not statistically different.

According to the OECD guide [47], the mortality of controls cannot exceed $10 \%$ in order for the test to be considered valid. Given that none of the four tests performed in this study exceeded this percentage, they could be regarded as such.

The $\mathrm{LC}_{50}$ values and $95 \%$ confidence intervals for $A$. salina exposed to the different substances are presented in Table 2.

Table 2. Forty-eight-hour $\mathrm{LC}_{50}$ values and confidence intervals for adult $A$. salina exposed to different toxicants (simvastatin, simvastatin $+\mathrm{MP}$, carbamazepine, carbamazepine $+\mathrm{MP}, \mathrm{CPF}, \mathrm{CPF}+\mathrm{MP}$, TCS and TCS $+\mathrm{MP})$.

\begin{tabular}{|c|c|c|}
\hline Emergent Contaminants & $\mathrm{LC}_{50}\left(\mathrm{mg} / \mathrm{dm}^{3}\right)$ & 95\% Limits \\
\hline Simvastatin & 9.35 & $8.58-10.43$ \\
\hline Simvastatin + MP & 10.29 & 9.34-12.02 \\
\hline Carbamazepine & 43.25 & $39.59-49.04$ \\
\hline Carbamazepine + MP & 46.50 & $41.95-55.72$ \\
\hline $\mathrm{CPF}$ & 0.006 & $0.002-0.009$ \\
\hline $\mathrm{CPF}+\mathrm{MP}$ & 0.012 & $0.001-0.018$ \\
\hline TCS & 4.979 & $2.096-6.0872$ \\
\hline $\mathrm{TCS}+\mathrm{MP}$ & 4.957 & $2.431-7.093$ \\
\hline
\end{tabular}

\subsection{Enzymatic Assay}

The results regarding cholinesterase activity in simvastatin, carbamazepine and both in association with MP are shown in Figure 4.
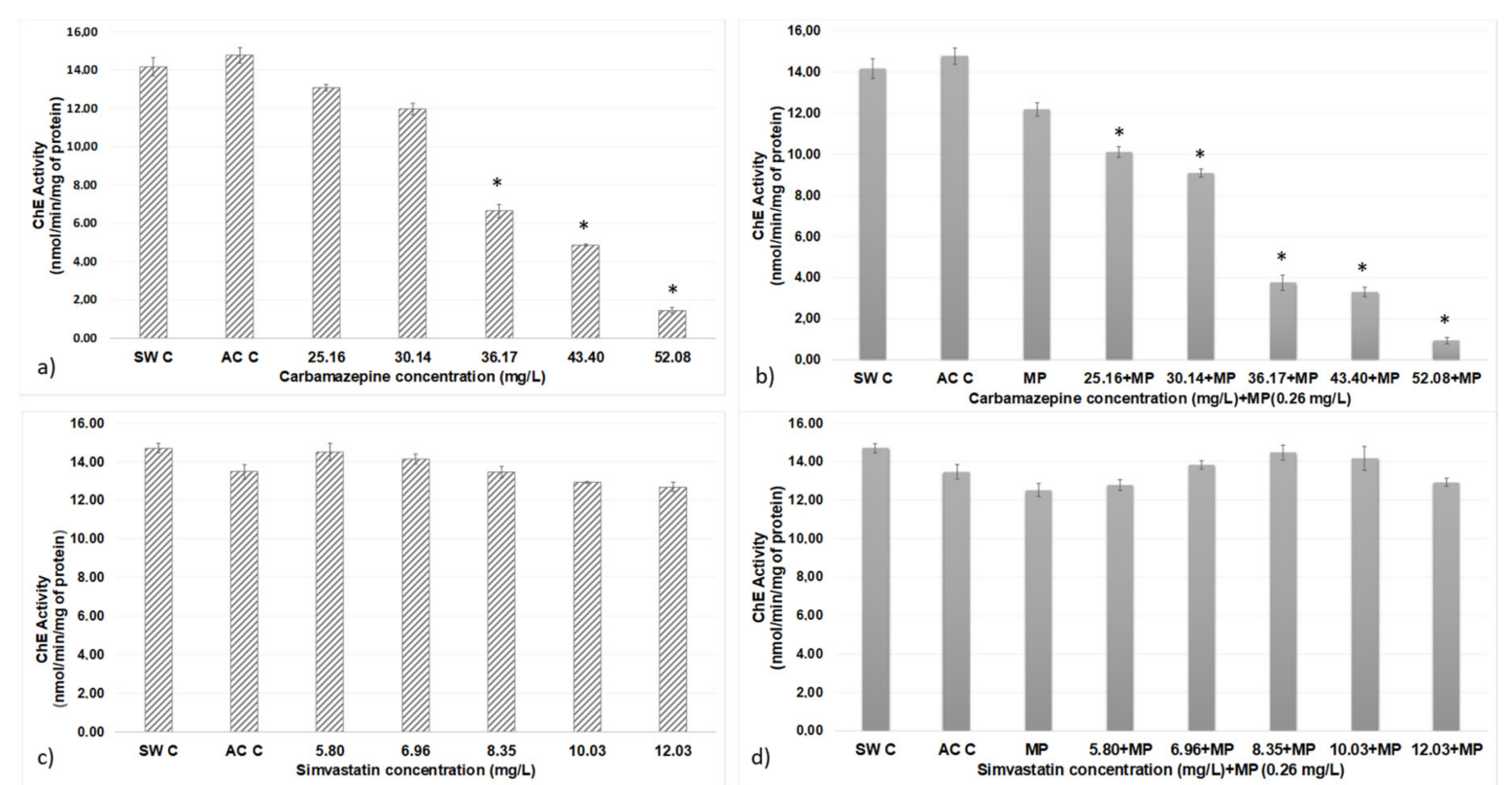

Figure 4. ChE activity of $A$. salina after $48 \mathrm{~h}$ of exposure to different contaminant concentrations: (a) simvastatin, (b) simvastatin $+\mathrm{MP},(\mathbf{c})$ carbamazepine and (d) carbamazepine + MP. Error bars represent standard deviations. * Significantly different between controls and other treatments $(p>0.05)$.

In the test with carbamazepine, statistically significant differences were obtained between the seawater and acetone controls at concentrations of $36.17,43.30$ and $52.08 \mathrm{mg} / \mathrm{dm}^{3}$; between the concentration of $25.16 \mathrm{mg} / \mathrm{dm}^{3}$ and the concentrations of $36.17,43.30$ and 
$52.08 \mathrm{mg} / \mathrm{dm}^{3}$; between the concentration of $30.14 \mathrm{mg} / \mathrm{dm}^{3}$ and the concentrations of $36.17,43.30$ and $52.08 \mathrm{mg} / \mathrm{dm}^{3}$; between the concentration of $36.17 \mathrm{mg} / \mathrm{dm}^{3}$ and that of $52.08 \mathrm{mg} / \mathrm{dm}^{3}$; and between the concentration of $43.30 \mathrm{mg} / \mathrm{dm}^{3}$ and that of $52.08 \mathrm{mg} / \mathrm{dm}^{3}$.

In the tests with carbamazepine $+\mathrm{MP}$, an increase in the inhibition of cholinesterase activity was observed versus only with carbamazepine treatments. After statistical analysis of the data, statistically significant differences were obtained between the controls for seawater, acetone and all concentrations of MP-associated carbamazepine that were used in the test. MPs showed significant differences with concentrations of 25.16, 30.14, 36.17, 43.40 and $52.08 \mathrm{mg} / \mathrm{dm}^{3}$. These differences were also determined between the concentration of $36.17 \mathrm{mg} / \mathrm{dm}^{3}$ and those of 25.16 and $30.14 \mathrm{mg} / \mathrm{dm}^{3}$, between the concentration of $43.30 \mathrm{mg} / \mathrm{dm}^{3}$ and those 25.16 and $30.14 \mathrm{mg} / \mathrm{dm}^{3}$ and between the concentration of $52.08 \mathrm{mg} / \mathrm{dm}^{3}$ and 25.16 and $30.14 \mathrm{mg} / \mathrm{dm}^{3}$.

In addition, the results obtained between the same concentrations of both assays were compared (simvastatin and MP associated with simvastatin), revealing no statistically significant differences.

The results of cholinesterase activity in CPF, TCS and either in association with MP are shown in Figure 5.
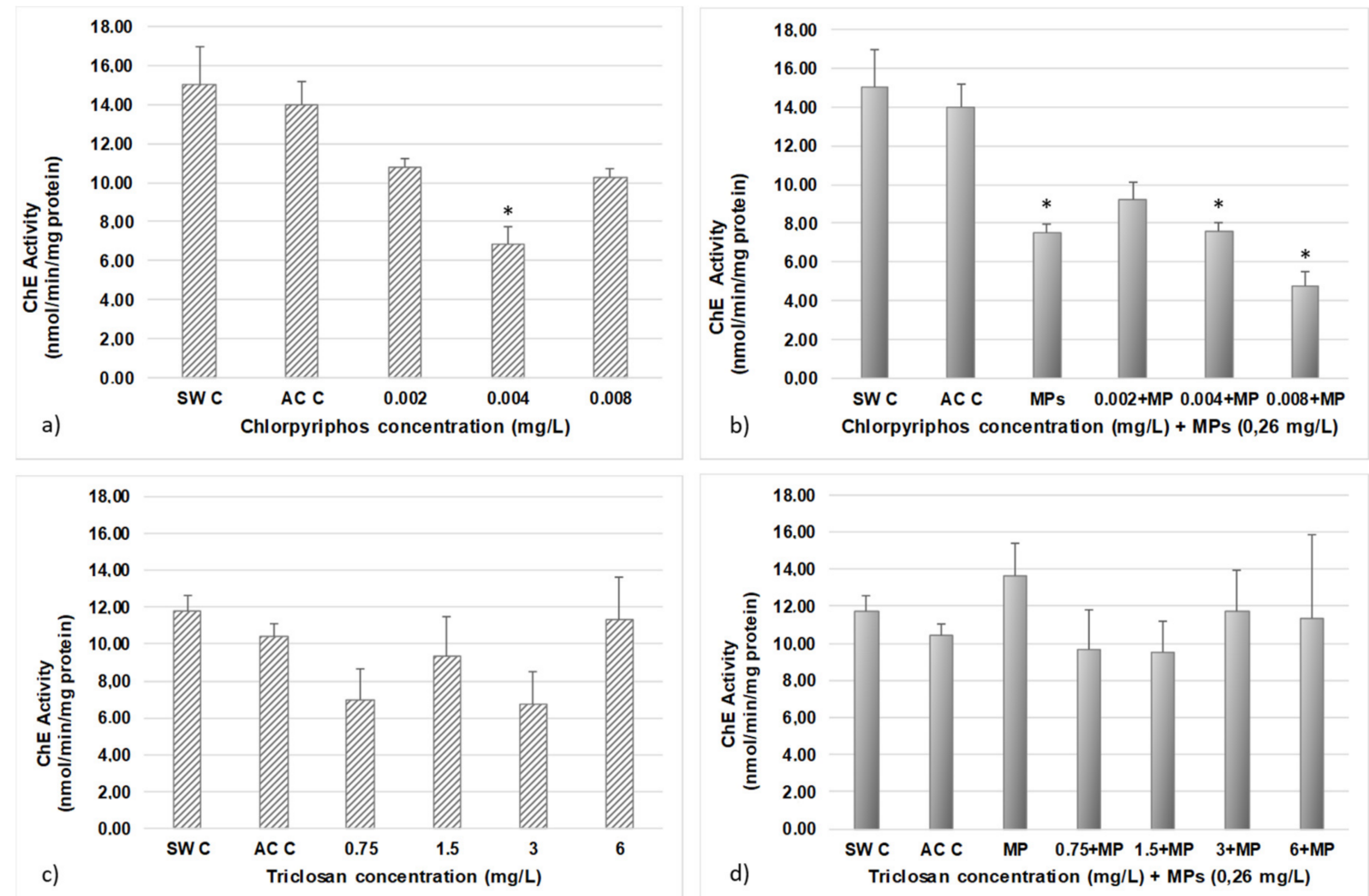

Figure 5. ChE activity of $A$. salina after $48 \mathrm{~h}$ of exposure to different contaminant concentrations: (a) CPF, (b) CPF $+\mathrm{MP}$, (c) TCS and (d) TCS + MP. Error bars represent standard deviations. * Significantly different between controls and other treatments $(p>0.05)$.

The concentration value of $0.008 \mathrm{mg} / \mathrm{dm}^{3} \mathrm{CPF}$ was considered abnormally high (possibly due to biological variability), so this result is disregarded in the Discussion section below.

Statistically significant differences in CPF + MP treatments were observed between the MP and the controls, between the concentrations of $0.004 \mathrm{mg} / \mathrm{dm}^{3}$ and the $0.008 \mathrm{mg} / \mathrm{dm}^{3}$ + MP, between $0.002 \mathrm{mg} / \mathrm{dm}^{3}$ and $0.004 \mathrm{mg} / \mathrm{dm}^{3}$ and $0.008 \mathrm{mg} / \mathrm{dm}^{3}+$ MP concentration, and between $0.002 \mathrm{mg} / \mathrm{dm}^{3}+\mathrm{MP}$ and $0.008 \mathrm{mg} / \mathrm{dm}^{3}+\mathrm{MP}$.

No differences were observed between equal concentrations of 0.002 and $0.004 \mathrm{mg} / \mathrm{dm}^{3}$ CPF with and without MP. 


\section{Discussion}

Pesticides, pharmaceuticals and MPs are environmental contaminants whose hazardous potential (especially in the case of the latter) have been ignored until relatively recently. Nevertheless, they can have direct effects on organisms, as well as act as vectors of other pollutants, potentially modifying their toxicity and bioavailability [32,33]. In this study, we observed the variability of responses between different pollutants with and without MP in the crustacean A. salina.

Among the values obtained for $\mathrm{LC}_{50}$, simvastatin was found to be most toxic $\left(\mathrm{LC}_{50}\right.$ of $\left.9.348 \mathrm{mg} / \mathrm{dm}^{3}\right)$, followed by the combination of simvastatin and MP $\left(\mathrm{LC}_{50}\right.$ of $\left.10.294 \mathrm{mg} / \mathrm{dm}^{3}\right)$, carbamazepine $\left(\mathrm{LC}_{50}\right.$ of $\left.43.225 \mathrm{mg} / \mathrm{dm}^{3}\right)$ and, finally, simvastatin with $\mathrm{MP}\left(\mathrm{LC}_{50}\right.$ of $46.503 \mathrm{mg} / \mathrm{dm}^{3}$ ). The presence of MPs in the treatments containing them showed a slight increase in $\mathrm{LC}_{50}$.

The $\mathrm{LC}_{50}$ of simvastatin has been determined in different crustaceans. Dahl et al. (2006) [52] observed a 96-h LC 50 of $810 \mu \mathrm{g} / \mathrm{dm}^{3}$ for Novanapis spinipes; however, Key et al. (2008) [53] observed a $96-\mathrm{h} \mathrm{LC}_{50}$ of $1.18 \mathrm{mg} / \mathrm{dm}^{3}$ for larvae of Palaemonetes pugio and more than $10 \mathrm{mg} / \mathrm{dm}^{3}$ for adult specimens of the same species, a value that was very similar to that obtained for A. salina $\left(9.348 \mathrm{mg} / \mathrm{dm}^{3}\right)$. In fish, Ribeiro et al. (2015) [54] studied the effects of simvastatin on zebrafish (Danio rerio), establishing an $\mathrm{LC}_{50}$ of $5 \mathrm{mg} / \mathrm{dm}^{3}$ for zebrafish embryos. Another study carried out by Key et al. (2009) [55] determined an $\mathrm{LC}_{50}$ of $2.68 \mathrm{mg} / \mathrm{dm}^{3}$ for Fundulus heteroclitus.

In A. salina, statistically significant differences were not recorded between the measures of cholinesterase activity in the control groups and the groups exposed to the different concentrations of simvastatin and simvastatin associated with MP tests. Similar results were observed by Key et al. (2009) [55] regarding simvastatin exposure for $96 \mathrm{~h}$ in Fundulus heteroclitus, although reduced cholinesterase activity declined slightly, if not significantly. In crustaceans, the test carried out by Key et al. (2008) [53] showed an $\mathrm{LC}_{50}$ of simvastatin in the range of 0.001 to $10 \mathrm{mg} / \mathrm{dm}^{3}$, which did not cause alterations in the acetylcholinesterase activity of larvae and adults of the shrimp Palaemonetes pugio. Considering that simvastatin is a commonly used and highly prescribed drug whose discharge into the aquatic environment has increased in recent years, it is reasonable to expect that its presence in the environment tends to increase and consequently enhance the risk of undesirable effects on the most sensitive species. For this reason and given this study's results, it is advisable to continue investigating the sublethal effects that this drug can cause, carrying out trials with other taxa and with organisms at different stages of development, using different biomarkers to assess the possible effects produced and increasing the time of exposure to the drug through chronic toxicity tests.

In the case of carbamazepine, the $48-\mathrm{h} \mathrm{LC}_{50}$ for Artemia salina was $43.225 \mathrm{mg} / \mathrm{dm}^{3}$. In other crustaceans, such as Daphnia magna, Kim et al. (2007) [56] estimated a 96-h LC 50 of $76.3 \mathrm{mg} / \mathrm{dm}^{3}$. A very similar concentration was obtained by Ferrari et al. (2004) [57]: a $48-\mathrm{h} \mathrm{LC}_{50}$ of $77.7 \mathrm{mg} / \mathrm{dm}^{3}$ in the same organism. These concentrations differ from those obtained in this work; hence, A. salina seems to be a more sensitive organism to carbamazepine than Daphnia magna. For the association of carbamazepine with MP, an $\mathrm{LC}_{50}$ of $46.503 \mathrm{mg} / \mathrm{dm}^{3}$ was obtained, which was higher (by $3.303 \mathrm{mg} / \mathrm{dm}^{3}$ ) than carbamazepine alone. A similar pattern was obtained with simvastatin. Besides, we observed that toxicity decreased in the combination of pharmaceuticals and MP. However, Brandts et al. (2018) [58] determined that exposure to carbamazepine associated with nanoplastics (polystyrene) induced a significant negative regulation in genetic expression in Mytilus galloprovincialis compared to exposure to carbamazepine only. In addition, studies carried out by Gambardella et al. (2017) [59] showed that exposure to MP (polystyrene) caused neurotoxic effects in nauplii of Artemia franciscana and Amphibalanus Amphitrite. Moreover, the ChE activity in carbamazepine and carbamazepina + MP exposed to A. salina was significantly inhibited in our study. Similar results have been obtained by other authors with different species of invertebrate organisms. For instance, Siebel et al. (2010) [60] observed via an in vitro test that carbamazepine inhibited acetylcholinesterase activity in 
the brain of zebrafish (Danio rerio). In crustaceans, Nkoom et al. (2019) [61] reported a significant decrease in acetylcholinesterase activity in Daphnia magna specimens exposed to concentrations of 5 and $100 \mu \mathrm{g} / \mathrm{L}$, as well as an ability to bioconcentrate in the aqueous medium under laboratory conditions. The $\mathrm{ChE}$ activity recorded in this test (carbamazepine + microplastic) was slightly lower than that obtained in the isolated carbamazepine test, but no statistically significant differences were obtained using the same concentrations in the two tests.

On the other hand, the smaller $\mathrm{LC}_{50}$ values from lowest to highest were: $\mathrm{CPF}, \mathrm{CPF}+$ MP and finally TCS + MP and TCS, which were similar. The value of $48-\mathrm{h} \mathrm{LC} 50$ for TCS $\left(4.979 \mathrm{mg} / \mathrm{dm}^{3}\right)$ obtained in this study was higher than associated values in the literature, probably related to the age of the crustaceans. For instance, Xu et al. (2015) [62] reported a 24-h $\mathrm{LC}_{50}$ of $0.171 \mathrm{mg} / \mathrm{dm}^{3}$ in a TCS toxicity test on A. salina (nauplium). Iannacone et al. (2016) [63] studied antimicrobial toxicity in Artemia franciscana (nauplii phase II), yielding a 48-h LC 50 of $0.72 \mathrm{mg} / \mathrm{dm}^{3}$. Perron et al. (2012) [23] investigated the effect of TCS on the invertebrates Ampelisca abdita and Americamysis bahia, reporting 48-h $\mathrm{LC}_{50}$ values of 0.0913 and $0.0956 \mathrm{mg} / \mathrm{dm}^{3}$, respectively. Regarding the effect of TCS in zebrafish (Danio rerio), Oliveira et al. (2009) [64] reported 96-h $\mathrm{LC}_{50}$ values of $0.42 \mathrm{mg} / \mathrm{dm}^{3}$ for embryos/larvae and $0.34 \mathrm{mg} / \mathrm{dm}^{3}$ for adults. These authors also examined variations in the values of biomarkers, including cholinesterase activity. They did not observe decreased enzymatic levels, similar to our study, where significant differences were not seen between the various concentrations tested and the control.

Sybeg et al. (2017) [65] tested with Acartia tonsa (adult) exposure to TCS alone and polyethylene $\left(500 \mathrm{MP} / \mathrm{cm}^{3}\right)$, yielding a $48-\mathrm{h} \mathrm{LC}_{50}$ of $0.1579 \mathrm{mg} / \mathrm{dm}^{3}$ for TCS and $0.1096 \mathrm{mg} / \mathrm{dm}^{3}$ for TCS + MP. With these data, the authors concluded that the mixture of TCS + MP was more toxic than TCS alone. These data disagree with our results, where no difference was observed between the $\mathrm{LC}_{50}$ of the TCS and TCS + MP.

Regarding A. salina, the $48-\mathrm{h} \mathrm{LC}_{50}$ values of $0.006 \mathrm{mg} / \mathrm{dm}^{3}$ and $0.012 \mathrm{mg} / \mathrm{dm}^{3}$ for $\mathrm{CPF}$ and $\mathrm{CPF}+\mathrm{MP}$, respectively, are in the range of those found by other authors in adults and juveniles. For instance, Osuna et al. (1997) [66] evaluated the toxicity to CPF in Penaeus sp. (juveniles), observing a $48-\mathrm{h} \mathrm{LC}_{50}$ of $0.00207 \mathrm{mg} / \mathrm{dm}^{3}$. Galindo et al. (1996) previously indicated a $48-\mathrm{h} \mathrm{LC}_{50}$ of $0.0048 \mathrm{mg} / \mathrm{dm}^{3}$ in a test with the crustacean Penaeus vannamei (juveniles) exposed to CPF.

Varó et al. (1998) [67] exposed to CPF on nauplii of different species of the genus Artemia sp. and observed differences in sensitivity to the toxic substance, indicating that the most sensitive species was Artemia salina (24-h $\mathrm{LC}_{50}$ from 0.95 to $5.12 \mathrm{mg} / \mathrm{dm}^{3}$ ). They also described differences that were not only based on the species tested (A. salina, A. persimilis, $A$. franciscana and $A$. parthenogenetica), but also between strains of the same species. Accordingly, these authors exposed to CPF in Artemia parthenogenetica, adult fish Gambusia affinis and Aphanius iberus and observed increased resistance to CPF in the genus Artemia compared to the two fish species (48-h LC 50 for G. affinis of $0.5 \mathrm{mg} / \mathrm{dm}^{3}$ and $48-\mathrm{h}$ $\mathrm{LC}_{50}$ for $A$. iberus of $0.0386 \mathrm{mg} / \mathrm{dm}^{3}$ ). In addition, the genus Artemia showed different sensitivity to the toxic substance according to the degree of development or intraspecific variability (nauplii $24-\mathrm{h} \mathrm{LC}_{50}$ : juveniles, $3.9 \pm 0.9 \mathrm{mg} / \mathrm{dm}^{3}$; adults, $0.08 \pm 0.01 \mathrm{mg} / \mathrm{dm}^{3}$ ).

Baek et al. (2015) [68] evaluated the effect of CPF, among other biocides, on A. salina (nauplium), yielding a 24-h $\mathrm{LC}_{50}$ of $2.032\left(0.416-6.891 \mathrm{mg} / \mathrm{dm}^{3}\right)$, within the range of Varó et al.'s (1998) [67] findings. In the same study, acetylcholinesterase activity was studied, comparing newborn nauplii with 48-h nauplii. The former was found to exhibit a greater decrease in cholinesterase activity than the 48-h nauplii, following exposure to CPF for $24 \mathrm{~h}$, rendering this a very useful marker for predicting signs of contamination by this toxic substance in the environment. The data from these studies indicate that there are differences in sensitivity, not only among species, but also depending on the stage of development. Adults and juveniles seem to be more sensitive than nauplii, so the choice of biomarker and developmental stage is of great importance in experiments to ensure a 
higher safety range. In our study, the $\mathrm{LC}_{50}$ data regarding $A$. salina were more in line with the values provided by these authors working with adults and juveniles.

The association of CPF with MP was not reflected in an increase in toxicity with CPF, as the $\mathrm{LC}_{50}$ value was higher. This toxicity-reducing effect has been mentioned by other authors [18], who have indicated that CPF adsorption to MP can reduce toxicity's effect on algal growth (Isochrysis galbana).

On the other hand, we observed a significant decrease in cholinesterase activity by the CPF + MP test, just as Oliveira et al. (2013) [69] and Luís et al. (2015) [45] found that acetylcholinesterase activity in samples of Pomatoschistus microps exposed to MP (polyethylene) to a 96-h test was lower than in a control. However, in the TCS + MP test, no significant differences were found, as has also been described by other researchers working with aquatic organisms $[64,70]$.

Organophosphate substances (CPFs) are known as prototype inhibitors of this enzyme. In fact, the specific activity of cholinesterase in A. salina decreases as concentrations of CPF increase [67]. Nevertheless, in this work, no statistically significant differences in cholinesterase activity were observed between equal concentrations of CPF with and without MP.

The results obtained indicate that the presence of MP in the medium reduces the toxicity, considering the $\mathrm{LC}_{50}$ values that may be related to the low MP intake detected in our preliminary test, since the concentration used $\left(0.26 \mathrm{mg} / \mathrm{dm}^{3}\right)$ was lower. This concentration was related to the concentration of MPs observed in the environmental. However, inhibition of cholinesterase activity of $A$. salina exposed with CPF, simvastatin and $\mathrm{CPF}+\mathrm{MP}$, simvastatin $+\mathrm{MP}$ in a concentration-dependent ratio showed a synergistic effect of MP+ other contaminants, probably due to their possible role as vehicles of exposure. Eder et al. (2021) [71] reviewed studies showing that the toxicity of pharmaceuticals and other particles and chemicals increased when exposure was combined with MP. Among the adverse effects, they distinguished the same biomarker studied in our work, the inhibition of cholinesterase activity. The synergistic effect could be determined by the sorption behavior of organic contaminants to MP that, according to Wang et al. (2020) [72], are partitioning, surface sorption and pore filling, as well as by the properties of the MP, organic contaminants and aquatic conditions. Thus, the interaction of MPs with contaminants can result in aggregation, reduced bioavailability and alteration in the toxicity to the organism [73].

\section{Conclusions}

In this study, the adverse effects of pharmaceutical compounds with associated MPs and pesticides with associated MPs were studied. Regarding 48-h LC 50 in A. salina, the MPs did not potentiate the adverse effects of pollutants when they were co-exposed; however, cholinesterase activity decreased more if the pollutant (drug or pesticide) was in contact with the MP than without them, indicating a cellular effect.

The concentration of MP exposed to A. salina was used by other authors for ecologically relevant studies, but the preliminary studies in this work with MP ingestion by organisms showed that, if the concentration of MP increased, the number of $A$. salina that incorporated MPs also increased, and this could suggest, that if the MP concentration increases in the environment, toxicity in the organism can also increase.

Author Contributions: Conceptualization, J.M.Q., J.M.A. and M.D.C.; methodology, V.A., C.G.-G. and M.G.A.; formal analysis, J.M.A., R.R.-B. and M.G.A.; investigation, J.M.A. and M.G.A.; data curation, J.M.A. and R.R.-B.; writing-original draft preparation, J.M.A. and V.A.; writing-review and editing, J.M.A. and M.D.C.; supervision, M.D.C. and J.M.A.; project administration, J.M.A.; funding acquisition, J.M.Q. and M.D.C. All authors have read and agreed to the published version of the manuscript.

Funding: This research was funded by the Ministerio de Ciencia, Investigación y Universidades (REF.: RTI2018-096771-B-100). 
Institutional Review Board Statement: Not applicable.

Informed Consent Statement: Informed consent was obtained from all subjects involved in the study.

Acknowledgments: The authors are grateful to the Laboratory of Marine Culture at University of Cádiz for providing the experimental fish used in this study.

Conflicts of Interest: The authors declare no conflict of interest.

\section{References}

1. Barboza, L.; Vieira, L.; Branco, V.; Figueiredo, N.; Carvalho, F.; Carvalho, C.; Guilhermino, L. Microplastics cause neurotoxicity, oxidative damage and energy-related changes and interact with the bioaccumulation of mercury in the European seabass, Dicentrarchus labrax (Linnaeus, 1758). Aquat. Toxicol. 2018, 195, 49-57. [CrossRef]

2. Fonte, E.; Ferreira, P.; Guilhermino, L. Temperature rise and microplastics interact with the toxicity of the antibiotic cefalexin to juveniles of the common goby (Pomatoschistus microps): Post-exposure predatory behaviour, acetylcholinesterase activity and lipid peroxidation. Aquat. Toxicol. 2016, 180, 173-185. [CrossRef]

3. Wardrop, P.; Shimeta, J.; Nugegoda, D.; Morrison, P.D.; Miranda, A.; Tang, M.; Clarke, B.O. Chemical pollutants sorbed to ingested microbeads from personal care products accumulate in fish. Environ. Sci. Technol. 2016, 50, 4037-4044. [CrossRef]

4. Ter Halle, A.; Jeanneau, L.; Martignac, M.; Jardé, E.; Pedrono, B.; Brach, L.; Gigault, J. Nanoplastic in the north atlantic subtropical gyre. Environ. Sci. Technol. 2017, 51, 13689-13697. [CrossRef]

5. Liu, Z.; Ojego, J.; Pruden, A.; Knowlton, K.F. Occurrence, fate and removal of synthetic oral contraceptives (SOCs) in the natural environment: A review. Sci. Total Environ. 2011, 409, 5149-5161. [CrossRef] [PubMed]

6. Biel-Maeso, M.; Baena-Nogueras, R.M.; Corada-Fernández, C.; Lara-Martín, P.A. Science of the Total Environment Occurrence, distribution and environmental risk of pharmaceutically active compounds (PhACs) in coastal and ocean waters from the Gulf of Cadiz (SW Spain). Sci. Total Environ. 2018, 612, 649-659. [CrossRef]

7. Barbosa, T.; Luiz Riveiro de Paiva, A.; Bezerra, M.M.M.; Carla, D.; Da Silva Pereira, J.J. Analysis of the presence of antiinflammatories drugs in surface water: A case study in Beberibe river-PE Brazil. Chemosphere 2019, 222, 961-996. [CrossRef]

8. Primrose, N.; Naicker, D.; Ncube, S.; Chimuka, L. Determination of naproxen, diclofenac and ibuprofen in Umgeni estuary and seawater: A case of northern Durban in KwaZulu-Natal Province of South Africa. Reg. Stud. Mar. Sci. 2019, $29,100675$.

9. AEMPS. Agencia Española de Medicamentes y Productos Sanitarios. Utilización de Medicamentos Hipolipemiantes en España Durante el Periodo 2000-2012. Informe de Utilización de Medicamentos U/HLP/V1/17012014. 2014. Available online: https: / / www.aemps.gob. es/?s=HIPOLIPEMIANTES (accessed on 13 May 2021).

10. AEMPS. Agencia Española de Medicamentes y Productos Sanitarios. Utilización de Medicamentos Antiepilépticos en España Durante el Periodo 2008-2016. Informe de Utilización de Medicamentos U/EPIL/V1/11/09/2017. 2017. Available online: https: / / www.aemps.gob.es/?s=antiepilepticos (accessed on 13 May 2021).

11. Hernando, M.; Heath, E.; Petrovic, M.; Barcelo, D. Trace-level determination of pharmaceutical residues by LC-MS/MS in natural and treated waters. A pilot-Survey Study. Anal. Bioanal. Chem. 2006, 385, 985-991. [CrossRef]

12. Neuparth, T.; Martins, C.; Santos, C.B.D.L.; Costa, M.H.; Martins, I.; Costa, P.M.; Santos, M.M. Hypocholesterolaemic pharmaceutical simvastatin disrupts reproduction and population growth of the amphipod Gammarus locusta at the ng/L range. Aquat. Toxicol. 2014, 155, 337-347. [CrossRef] [PubMed]

13. Ellesat, K.S.; Tollefsen, K.; Åsberg, A.; Thomas, K.V.; Hylland, K. Cytotoxicity of atorvastatin and simvastatin on primary rainbow trout (Oncorhynchus mykiss) hepatocytes. Toxicol. In Vitro 2020, 24, 1610-1618. [CrossRef] [PubMed]

14. Chen, H.; Gu, X.; Zeng, Q.; Mao, Z.; Liang, X.; Martyniuk, C.J. Carbamazepine disrupts molting hormone signaling and inhibits molting and growth of Eriocheir sinensis at environmentally relevant concentrations. Aquat. Toxicol. 2019, 208, 138-145. [CrossRef] [PubMed]

15. Franzellitti, S.; Canesi, L.; Rajapaksha, M.A.; Whathsala, H.G.R.; Fabri, E. Microplastic exposure and effects in aquatic organisms: A physiological perspective Environ. Toxicol. Pharm. 2019, 68, 37-51. [CrossRef]

16. Weichert, F.G.; Floeter, C.; Meza, A.S.; Kammann, U. Assessing the ecotoxicity of potentially neurotoxic substances-Evaluation of a behavioural parameter in the embryogenesis of Danio rerio. Chemosphere 2017, 186, 43-50. [CrossRef]

17. De Souza, R.M.; Seibert, D.; Quesada, H.B.; Basetti, F.J.; Fagundes-Klen, M.R.; Bergamasco, R. Occurrence, impacts and general aspects of pesticides in surface water: A review. Process Saf. Environ. Protect. 2020, 135, 22-37. [CrossRef]

18. Garrido, S.; Linares, M.; Campillo, A.J.; Albentosa, M. Effect of microplastics on the toxicity of chlorpyrifos to the microalgae Isochrysis galbana, clone T-ISO. Ecotox. Environ. Saf. 2019, 173, 103-109. [CrossRef]

19. Huang, X.; Duan, W. Ecotoxicity of chlorpyrifos to aquatic organisms: A review. Ecotox. Environ. Saf. 2020, 200, 110731. [CrossRef] [PubMed]

20. Albers, J.W.; Berent, S.; Garabrant, D.H.; Giordani, B.; Schweitzer, S.J.; Garrison, R.P.; Richardson, R.J. The effects of occupational exposure to chlorpyrifos on the neurologic examination of central nervous system function: A prospective cohort study. J. Occup. Environ. Med. 2004, 46, 367-378. [CrossRef] [PubMed]

21. Racke, K.D. Environmental fate of chlorpyrifos. Rev. Environ. Contam. Toxicol. 1993, 131, 1-154. [PubMed] 
22. McAvoy, D.C.; Schatowitz, B.; Jacob, M.; Hauk, A.; Eckhoff, W.S. Measurement of triclosan in wastewater treatment systems. Environ. Toxicol. Chem. 2002, 21, 1323-1329. [CrossRef]

23. Perron, M.M.; Ho, K.T.; Cantwell, M.G.; Burgess, R.M.; Pelleterier, M.C. Effects of triclosan on marine benthic and epibenthic organisms. Environ. Toxicol. Chem. 2012, 31, 1861-1866. [CrossRef] [PubMed]

24. Ishibashi, H.; Matsumura, N.; Hirano, M.; Matsuoka, M.; Shiratsuchi, H.; Ishibashi, Y.; Takao, Y.; Arizono, K. Effects oftriclosan on the early life stages and reproduction of medaka Oryzias latipes and induction of hepatic vitellogenin. Aquat. Toxicol. 2007, 67, 167-179. [CrossRef]

25. Levy, C.W.; Roujeinikova, A.; Sedelnikova, S.; Baker, P.J.; Stuitje, A.R.; Slabas, A.R.; Rice, D.W.; Raffertu, K.-B. Molecular basis of triclosan activity. Nature 1999, 398, 383-384. [CrossRef] [PubMed]

26. Plastics Europe. An Analysis of European Plastics Production, Demand and Waste Data. Plastics-the Facts. 2019. Available online: https:/ / www.plasticseurope.org/es/resources/publications/1804-plastics-facts-2019 (accessed on 13 May 2021).

27. Lestari, P.; Trihadiningrum, Y. The impact of improper solid waste management to plastic pollution in Indonesian coast and marine environment. Mar. Pollut. Bull. 2019, 149, 110505. [CrossRef] [PubMed]

28. Deudero, S.; Alomar, C. Mediterranean marine biodiversity under threat: Reviewing influence of marine litter on species. Mar. Pollut. Bull. 2015, 98, 58-68. [CrossRef] [PubMed]

29. Magni, S.; Binelli, A.; Pittura, L.; Giacomo, C.; Della, C.; Carla, C.; Regoli, F. The fate of microplastics in an Italian Wastewater Treatment Plant. Sci. Total Environ. 2019, 652, 602-610. [CrossRef] [PubMed]

30. Franco, A.A.; Arellano, J.M.; Albendín, G.; Rodríguez-Barroso, R.; Zahedi, S.; Quiroga, J.M.; Coello, M.D. Mapping microplastics in Cadiz (Spain): Occurrence of microplastics inmunicipal and industrial wastewaters. J. Water Process Eng. 2020, $38,101596$. [CrossRef]

31. Franco, A.A.; Arellano, J.M.; Albendín, G.; Rodríguez-Barroso, R.; Quiroga, J.M.; Coello, M.D. Microplastic pollution in wastewater treatment plants in the city of Cádiz: Abundance, removal efficiency and presence in receiving water body. Sci. Total Environ. 2021, 776, 145795. [CrossRef]

32. Yuan, W.; Zhou, Y.; Chen, Y.; Liu, X.; Wang, J. Toxicological effects of microplastics and heavy metals on the Daphnia magna. Sci. Total Environ. 2020, 746, 141254. [CrossRef] [PubMed]

33. Li, J.; Zhang, K.; Zhang, H. Adsorption of antibiotics on microplastics. Environ. Pollut. 2018, 237, 460-467. [CrossRef]

34. Rainieri, S.; Conlledo, N.; Larsen, B.K.; Granby, K.; Barranco, A. Combined effects of microplastics and chemical contaminants on the organ toxicity of zebra fish (Danio rerio). Environ. Res. 2018, 162, 135-143. [CrossRef]

35. Webb, S.; Gawa, S.; Marsdenb, I.D.; McRae, N.K. Biomarker responses in New Zealand green-lipped mussels Perna canaliculus exposed to microplastics and triclosan. Ecotoxicol. Environ. Saf. 2020, 201, 110871. [CrossRef]

36. Choi, J.Y.; Yu, J.; Yang, D.B.; Ra, K.; Kin, K.T.; Hong, G.H.; Shin, K.H. Acetylthiocholine (ATC)-Cleaving cholinesterase (ChE) activity as a potential biomarker of pesticide exposure in the Manila clam, Ruditapes philippinarum, of Korea. Mar. Environ. Res. 2011, 71, 162-168. [CrossRef]

37. Thi, H.; Silvestre, F.; Scippo, M.; Thome, J.; Thanh, N.; Kestemont, P. Acetylcholinesterase activity as a biomarker of exposure to antibiotics and pesticides in the black tiger shrimp (Penaeus monodon). Ecotoxicol. Environ. Saf. 2009, 72, 1463-1470. [CrossRef]

38. Albendín, M.G.; Mánuel-Vez, M.P.; Arellano, J.M. In vivo cholinesterase sensitivity of gilthead seabream (Sparus aurata) exposed to organophosphate compounds: Influence of biological factors. Ecol. Indic. 2021, 121, 107176. [CrossRef]

39. Soto-Mancera, F.; Arellano, J.M.; Albendín, M.G. Carboxylesterase in Sparus aurata: Characterisation and sensitivity to organophosphorus pesticides and pharmaceutical products. Ecol. Indic. 2020, 109, 105603. [CrossRef]

40. Nunes, B.; Carvalho, F.; Guilhermino, L. Effects of widely used pharmaceuticals and a detergent on oxidative stress biomarkers of the crustacean Artemia parthenogenetica. Chemosphere 2006, 62, 581-594. [CrossRef] [PubMed]

41. Yu, P.; Liu, Z.; Wu, D.; Chen, M.; Lv, W.; Zhao, Y. Accumulation of polystyrene microplastics in juvenile Eriocheir sinensis and oxidative stress effects in the liver. Aquat. Toxicol. 2018, 200, 28-36. [CrossRef] [PubMed]

42. Migliore, L.; Civitareale, C.; Brambilla, G.; Di Delupis, D.G. Toxicity of several important agricultural to Artemia. Water Res. 1997, 31, 1801-1806. [CrossRef]

43. Libralato, G.; Prato, E.; Migliore, L.; Cicero, A.M.; Manfra, L. A review of toxicity testing protocols and endpoints with Artemia spp. Ecol. Indic. 2016, 69, 35-49. [CrossRef]

44. Wang, Y.; Zhang, D.; Zhang, M.; Mu, J.; Ding, G.; Mao, Z.; Cao, Y.; Jin, F.; Cong, Y.; Wang, L.; et al. Effects of ingested polystyrene microplastics on brine shrimp, Artemia parthenogenetica. Environ. Pollut. 2019, 244, 715-722. [CrossRef]

45. Luís, L.G.; Ferreira, P.; Fontea, E.; Oliveira, M.; Guilhermino, L. Does the presence of microplastics influence the acute toxicity of chromium (VI) to early juveniles of the common goby (Pomatoschistus microps)? A study with juveniles from two wild estuarine populations. Aquat. Toxicol. 2015, 164, 163-174. [CrossRef] [PubMed]

46. Barboza, L.G.A.; Vieiro, L.R.; Gilhermino, L. Single and combined effects of microplastics and mercury on juveniles of the European seabass (Dicentrarchus labrax): Changes in behavioural responses and reduction of swimming velocity and resistance time. Environ. Pollut. 2018, 236, 1014-1019. [CrossRef] [PubMed]

47. OECD. Daphnia sp., Acute Immobilisation. Guideline for testing of chemicals, 202. 2004. Available online: https://www.oecd.org/ env/ehs/testing/Full\%20list\%20of\%20Test\%20Guidelines\%20in\%20English\%20September\%20\%202014.pdf (accessed on 13 May 2021). 
48. Ellman, G.L.; Courtney, K.D.; Andres, V.; Featherstone, R.M. A new and rapid colorimetric determination of acetylcholinesterase activity. Biochem. Pharma 1961, 7, 88-95. [CrossRef]

49. Albendín, G.; Arellano, J.M.; Mánuel-Vez, M.P.; Sarasquete, C.; Arufe, M.I. Characterization and in vitro sensitivity of cholinesterases of gilthead seabream (Sparus aurata) to organophosphate pesticides. Fish Physiol. Biochem. 2017, 43, 455-464. [CrossRef]

50. Bradford, M.M. A Rapid and Sensitive Method for the Quantitation Microgram Quantities of Protein Utilizing the Principle of Protein-Dye Binding. Anal. Biochem. 1976, 254, 248-254. [CrossRef]

51. Goldstein, M.C.; Rosenberg, M.; Cheng, L. Increased oceanic microplastic debris enhances oviposition in an endemic pelagic insect. Biol. Lett. 2021, 8, 817-820. [CrossRef]

52. Dahl, U.; Gorokhova, E.; Breitholtz, M. Application of growth-related sublethal endpoints in ecotoxicological assessments using a harpacticoid copepod. Aquat. Toxicol. 2006, 77, 433-438. [CrossRef]

53. Key, P.B.; Hoguet, J.; Reed, L.A.; Chung, K.W.; Fulton, M.H. Effects of the Statin Antihyperlipidemic Agent Simvastatin on Grass Shrimp, Palaemonetes pugio. Environ. Toxicol. 2008, 23, 153-160. [CrossRef]

54. Ribeiro, S.; Torres, T.; Martins, R.; Santos, M.M. Toxicity screening of diclofenac, propranolol, sertraline and simvastatin using Danio rerio and Paracentrotus lividus embryo bioassays. Ecotox. Environ. Saf. 2015, 114, 67-74. [CrossRef]

55. Key, P.B.; Hoguet, J.; Chung, K.W.; Venturella, J.J.; Pennington, P.L.; Fulton, M.H. Lethal and sublethal effects of simvastatin, irgarol, and PBDE-47 on the estuarine fish, Fundulus heteroclitus. J. Environ. Sci. Health 2009, 1234, 379-382. [CrossRef]

56. Kim, Y.; Choi, K.; Jung, J.; Park, S.; Kim, P.G.; Park, J. Aquatic toxicity of acetaminophen, carbamazepine, cimetidine, diltiazem and six major sulfonamides, and their potential ecological risks in Korea. Environ. Int. 2007, 33, 370-375. [CrossRef] [PubMed]

57. Ferrari, B.; Mons, R.; Vollat, B.; Fraysse, B.; Paxéus, N.; Lo Giudice, R.; Pollio, A.; Garric, J. Environmental risk assessment of six human pharmaceuticals: Are the current environmental risk assessment procedures sufficient for the protection of the aquatic environment? Environ. Toxicol. Chem. 2004, 23, 1344-1354. [CrossRef] [PubMed]

58. Brandts, I.; Teles, M.; Gonçalves, A.P.; Barreto, A.; Franco-Martinez, L.; Tvarijonaviciute, A.; Martins, M.A.; Soares, A.M.V.M.; Tort, L.; Oliveira, M. Effects of nanoplastics on Mytilus galloprovincialis after individual and combined exposure with carbamazepine. Sci. Total Environ. 2018, 643, 775-784. [CrossRef]

59. Gambardella, C.; Morgana, S.; Ferrando, S.; Bramini, M.; Piazza, V.; Costa, E.; Garaventa, F.; Faimali, M. Effects of polystyrene microbeads in marine planktonic crustaceans. Ecotox. Environ. Saf. 2017, 145, 250-257. [CrossRef] [PubMed]

60. Siebel, A.M.; Rico, E.P.; Capiotti, K.M.; Piato, A.L.; Cusinato, C.T.; Franco, T.M.A.; Bogo, M.R.; Bonan, C.D. Toxicology in Vitro In vitro effects of antiepileptic drugs on acetylcholinesterase and ectonucleotidase activities in zebrafish (Danio rerio) brain. Toxicol. In Vitro 2010, 24, 1279-1284. [CrossRef]

61. Nkoom, M.; Lu, G.; Liu, J.; Yang, H.; Dong, H. Bioconcentration of the antiepileptic drug carbamazepine and its physiological and biochemical effects on Daphnia magna. Ecotox. Environ. Saf. 2019, 172, 11-18. [CrossRef]

62. Xu, X.; Lu, Y.; Zhang, D.; Wang, Y.; Zhou, X.; Xu, H.; Mei, Y. Toxic Assessment of Triclosan and Triclocarban on Artemia salina. Bull. Environ. Contam. Toxicol. 2015, 95, 728-733. [CrossRef]

63. Iannacone, J.J.; Alvariño, L.; Valle Riestra, V.; Ymaña, B.; Argota, G.; Fimia, F.; Carhuapoma, M.; Castañeda, L. Toxicidad de agentes antiparasitarios, antimicrobianos e insecticidas sobre larvas del camarón salino Artemia franciscana (Crustacea: Artemiidae). Rev. Toxicol. 2016, 33, 1-38.

64. Oliveira, R.; Domingues, I.; Grisolia, C.K.; Soares, A.M. Effects of triclosan on zebrafish early-life stages and adults. Environ. Sci. Pollut. Res. Int. 2009, 16, 679-688. [CrossRef]

65. Syberg, K.; Nielsen, A.; Khan, F.R.; Banta, G.T.; Palmqvist, A.; Jepsen, P.M. Microplastic potentiates triclosan toxicity to the marine copepod Acartia tonsa. J. Toxicol. Environ. Health 2017, 80, 23-24. [CrossRef]

66. Osuna, I.; López, D.; Galindo, J.G.; Riva, M.C. Evaluación ecológica del metilparatión, metilazinfós, clorpirifos, diazinón y metamidofos, en camarones del género Penaueus sp. Bol. Intexter 1997, 111, 65-71.

67. Varó, I.; Serrano, R.; Navarro, J.C.; Lopez, F.J.; Amat, F. Acute lethal toxicity of the organophosphorus pesticide Chlorpyrifos to different species and strains of Artemia. Bull. Environ. Contam. Toxicol. 1998, 61, 778-785. [CrossRef]

68. Baek, I.; Choi, H.J.; Rhee, J.S. Inhibitory effects of biocides on hatching and acetylcholinesterase activity in the brine shrimp Artemia salina. Toxicol. Environ. Health Sci. 2015, 7, 303-308. [CrossRef]

69. Oliveira, M.; Ribeiro, A.; Hylland, K.; Guilhermino, L. Single and combined effects of microplastic and pyrene on juveniles (0+ group) of the common goby Pomatoschistus microps. Ecol. Indic. 2013, 34, 641-647. [CrossRef]

70. Albendín, G.; Cabrera-Pozo, I.; Coello, D.; Rodríguez-Barroso, R.; Quiroga, J.M.; Arellano, J.M. Effects of triclosan and its mixed with microplastics on acetylcholinesterase present on head of Solea senegalensis. In XIX Seminario Ibérico de Química Marina; Cobelo, A., Nieto, O., Viñas, L., Álvarez-Salgado, X.A., Eds.; Universidade de Vigo: Vigo, Spain, 2018; pp. 97-98.

71. Eder, M.L.; Oliva-Teles, L.; Pinto, R.; Carvalho, A.P.C.; Almeida, C.M.; Hornek-Gausterer, R.; Guimaraes, L. Microplastics as a vehicle of exposure to chemical contamination in freshwater systems: Current research status and way forward. J. Hazard. Mater. 2017, 417, 125980. [CrossRef] [PubMed]

72. Wang, F.; Zhang, M.; Sha, W.; Wang, Y.; Hao, H.; Dou, Y.; Li, Y. Rewiew: Sorption behaviour and mechanisms of organic contaminants to nano and microplastics. Molecules 2020, 25, 1827. [CrossRef] [PubMed]

73. Bhagat, J.; Nishimura, N.; Shimada, Y. Toxicological interactions of microplastics/nanoplastics and environmental contaminants: Current knowledge and future perspectives. J. Hazard. Mater. 2020, 405, 123913. [CrossRef] 